\title{
The characterization and sequence analysis of thirty CTG-repeat containing genomic cosmid clones
}

R obert A Philibert ${ }^{1}$, Nina H orelli-Kuitunen ${ }^{2}, A$ delaide S R obb ${ }^{1}, Y$ u-H sien L ee ${ }^{1}$, R obert $\mathrm{T}_{\text {L ong }}{ }^{1}$, Patricia Damschroder-Williams ${ }^{1}$, Brian M Martin ${ }^{1}$, M iles B B rennan ${ }^{1}, A$ arno Palotie ${ }^{2}$ and Edward I Ginns ${ }^{1}$

${ }^{1} \mathrm{C}$ linical $\mathrm{N}$ euroscience $\mathrm{B}$ ranch, $\mathrm{N}$ ational Institute of $\mathrm{M}$ ental $\mathrm{H}$ ealth, $\mathrm{N}$ ational Institutes of $\mathrm{H}$ ealth, $\mathrm{B}$ ethesda, $\mathrm{MD}$ 20892-4405, USA

${ }^{2} \mathrm{D}$ epartment of Clinical Chemistry, L aboratory of M olecular G enetics, $\mathrm{H}$ elsinki University Central Hospital, $\mathrm{H}$ elsinki, Finland

\begin{abstract}
We have systematically isolated and characterized DNA containing large CTG $(n>7)$ repeats from a human cosmid genomic DNA library. Using a CTG $_{10}$ probe, more than 100 cosmid clones were identified, and 30 of these have been extensively characterized. The sequenced cosmids contain repeats that are between three and 19 perfect units (average 10 perfect repeats). The cosmids map to at least 12 different chromosomes. Sequence analysis of flanking regions suggests that more than one third of the repeats occur in exons, and many share strong sequence identity with databank sequences, including the gene involved in dentatorubral pallidoluysian atrophy (DRPLA). Genotyping of human DNA samples demonstrates that more than half of the repeats are polymorphic. This and similar collections of clones containing trinucleotide repeats should aid in the identification of genes that may contain expansions of trinucleotide repeats involved in human disease.
\end{abstract}

Keywords: trinucleotide repeat; cosmid; fluorescent in situ hybridization (FISH); sequence analysis

\section{Introduction}

Pathological expansion of trinucleotide repeats ${ }^{1}$ is responsible for several human diseases, including $\mathrm{H}$ untington's chorea, ${ }^{2}$ spinocerebellar ataxias, ${ }^{3}$ spinal bulbar muscular atrophy and dentatorubral pallidoluysian atrophy (DRPLA) ${ }^{5}$ and myotonic dystrophy. ${ }^{6,7}$ In each of these disorders, normally polymorphic repetitive DNA regions of between 10 and 30 perfect CTG or

Correspondence: Robert A Philibert, Clinical Neuroscience B ranch, National Institute of $M$ ental Health, Building 49, R oom B IE E 16, 49 Convent D rive, M SC 4405, B ethesda, M D 20892, U SA

A ccepted 100 ctober 1997
CA G units expand to greater than 40 units, resulting in disruptions of gene function.

Previously, investigators have attempted to isolate and characterize segments of DNA containing large $C T G$ repeats from $C D N A$ rather than genomic libraries. $^{8-11}$ While all CTG repeats associated with disease ${ }^{1}$ should be represented, their isolation using CDNA libraries can be quite difficult for several reasons. First, low copy number, unstable, or tissue specific RNAs may be under-represented or completely absent from certain CDNA libraries. ${ }^{12}$ Second, this approach of screening for CDNA will not identify trinucleotide containing regions in introns or in regions flanking genes. Third, trinucleotide repeats may not subclone in 
the vectors commonly used to generate cDNA libraries.

In order to circumvent these difficulties and to obtain as complete a representation as possible, we isolated and characterized trinucleotide repeats from a genomic DNA library and directly sequenced the cosmid genomic DNA inserts. ${ }^{13}$ In this report, we describe our findings from the study of 30 trinucleotide repeat containing genomic clones.

\section{Materials and Methods}

The cosmid library was constructed from human DNA, partially digested with Sau $3 \mathrm{~A}$, ligated into the SuperCos I cosmid vector (Stratagene, L a J olla, CA ), and packaged using the Gigapak II (Stratagene, La Jolla, CA ). Positive colonies were identified by hybridization using the oligonucleotide probe $\mathrm{CTG}_{10}{ }^{14}{ }^{14}$ B riefly, three replicate cosmid colony lifts were prepared using ICN (Costa Mesa, CA) Biotrans membrane and then prehybridized for one hour in buffer $(5 \times \mathrm{SSPE}, \mathrm{pH} 7.0,10 \times$ D enhardt's solution, $0.05 \% \mathrm{SDS}$, and $10 \mu \mathrm{g} / \mathrm{ml}$ sheared $E$. coli DNA), and finally hybridized overnight in buffer $(5 \times$ SSPE, pH 7.0, $5 \times$ D enhardt's solution, $0.1 \%$ SDS, and $10 \mu \mathrm{g} / \mathrm{ml}$ sheared $E$. coli DNA) containing $5^{\prime} \mathrm{P}^{32}$ labeled $\mathrm{CTG}_{10}$ probe. Individual sets of filters were then washed initially with two consecutive $5 \mathrm{~min}$ washes that were followed by more stringent washes at either $60^{\circ} \mathrm{C}, 70^{\circ} \mathrm{C}$ or $80^{\circ} \mathrm{C}$ for $15 \mathrm{~min}$ in $6 \times \mathrm{SSPE}$. Filters were then exposed to $\mathrm{X}$-ray film (Kodak X-OMAT-AR) for approximately $16 \mathrm{~h}$ at $-70^{\circ} \mathrm{C}$. Cosmid DNA was prepared and sequenced using either manual radioactive or automated fluorescent methods as described previously. ${ }^{13}$

\section{PCR Amplification}

PCR amplification of trinucleotide repeat containing DNA was performed using standard PCR buffer $(10 \mathrm{mM}$ Tris- $\mathrm{HCl}$ (pH 8.3), $50 \mathrm{mM} \mathrm{KCl}, 0.001 \%$ gelatin, $2 \mathrm{mM} \mathrm{M} \mathrm{gCl} 2,200 \mu \mathrm{m}$ of each deoxynucleotide), $0.8 \mu \mathrm{m}$ primers and $10 \%$ D M SO. Taq polymerase and genomic DNA concentrations were $2.5 \mathrm{U} / 100 \mu \mathrm{l}$ and $50 \mathrm{ng} / 100 \mu \mathrm{l}$, respectively. The thermal cycling parameters for amplification were: initial denaturation of $95^{\circ} \mathrm{C}$ for $5 \mathrm{~min}$, then $45 \mathrm{cycles}$ of $95^{\circ} \mathrm{C} \times 1 \mathrm{~min}, 65^{\circ} \mathrm{C} \times 30 \mathrm{~s}$, and $72^{\circ} \mathrm{C} \times 2 \mathrm{~min}$, followed by an final extension at $72^{\circ} \mathrm{C} \times 10 \mathrm{~min}$.

\section{Polymorphism Analysis}

Polymorphism analysis was conducted using DNAs from more than 30 unrelated individuals. The PCR products were exposed to electrophoresis at 1700 volts for $2-3 \mathrm{~h}$ on a $6 \%$ denaturing polyacrylamide sequencing gel. The separated $\mathrm{PCR}$ products were then electroblotted on to a $\mathrm{Hy}$-bond $\mathrm{N}+$ membrane (A mersham UK), hybridized overnight at $42^{\circ} \mathrm{C}$ in buffer $\left(0.25 \mathrm{M} \mathrm{NaCl}, 0.125 \mathrm{M} \mathrm{NaPO}_{4}, 10 \%\right.$ polyethylene glycol (MW6000), and 6\% SDS) to a ${ }^{32}$ P-labeled $\mathrm{CTG}_{10}$ probe, then washed, first at room temperature and then at $37^{\circ} \mathrm{C}$, for $1 \mathrm{~h}$ with wash buffer $(2 \times \mathrm{SSC} / 1 \%$ SD S $)$. Filters were then exposed overnight to Kodak X-O M AT-A R film at $-70^{\circ} \mathrm{C}$. The size of $P C R$ products was determined by comparison with DNA sequencing ladder DNA fragments.

\section{Sequence Analysis}

Sequence analysis was performed using the BLAST ${ }^{15}$ and G R A IL (O akridge N ational L aboratory) ${ }^{16,17}$ programs. D atabase comparisons and analyses were conducted on the cosmid DNA sequences with and without the trinucleotide repeat regions (see $\mathrm{R}$ esults).

\section{Chromosome Localization and Subchromosome Localization}

Chromosomal assignment of the trinucleotide repeats was performed by PCR of somatic cell hybrid DNA (M PD-5000) from Bios Laboratories (New Haven, Connecticut).

\section{Target Material for Fluorescence in situ Hybridization} (FISH)

Peripheral blood lymphocytes were cultured according to standard protocols, and cells were treated with 5-bromodeoxyuridine (Brdu) at early replicating phase to induce banding pattern. ${ }^{18}$ Slides were stained with $\mathrm{H}$ oechst $33258(1 \mu \mathrm{g} / \mathrm{ml})$ for $10 \mathrm{~min}$ and exposed to UV light ( $302 \mathrm{~nm}$ ) for $30 \mathrm{~min} .{ }^{19}$ B efore hybridization metaphase slides were pretreated with R NA se $(100 \mu \mathrm{g} / \mathrm{ml})$ and pepsin $(20 \mu \mathrm{g} / \mathrm{ml})$.

\section{Probes for FISH}

CTG -containing cosmids were labeled with biotin 11-dU TP (Sigma Chemicals) by nick translation according to standard protocols (Nick Translation Kit, BRL).

\section{FISH}

The FISH procedure was carried out using $50 \%$ formamide, $10 \%$ dextran sulfate in $2 \times$ SSC as described earlier. . $^{19-22}$ Repetitive sequences were suppressed with 10-30 fold excess of COT-1 DNA (BR L, G aithersburg, MD). A fter overnight incubation, nonspecific hybridization signals were eliminated by washing the slides with $50 \%$ formamide $/ 2 \times$ SSC, twice with $2 \times \mathrm{SSC}$, and once with $0.5 \times \mathrm{SSC}$ at $45^{\circ} \mathrm{C}$. Specific hybridization signals were visualized using FITC-conjugated $A$ vidin (Vector L aboratories) and slides were counterstained with DAPI (4'-6'-diamino-2-phenylindole) $(0.025 \mu \mathrm{g} / \mathrm{ml})$. Only double spot signals were considered to be specific hybridizations. A multi-color image analysis was used for acquisition, display and quantification of hybridization signals of metaphase chromosomes. The system consists of a Photometrics PXL camera (Photometrics Inc, Tucson, A Z) attached to a PowerM ac7100/A v workstation. I PL ab software controls the camera operation, image acquisition and Ludl wheel. ${ }^{23}$

\section{Results}

From 800000 human genomic cosmid clones screened with a ${ }^{32} \mathrm{P}$-labeled $\mathrm{CTG}_{10}$ probe, 100 cosmids with positive hybridization signals were purified, and 30 were sequenced using the degenerate primer method. ${ }^{13}$ of these, 22 repeat sequences were unique whereas eight were represented twice. The chromosomal localization, length of the trinucleotide repeat, the heterozygosity, as well as the PCR primer sequences used to amplify the repeat region are shown in Table 1 . A Ithough the repeats average almost 10 perfect repeat 


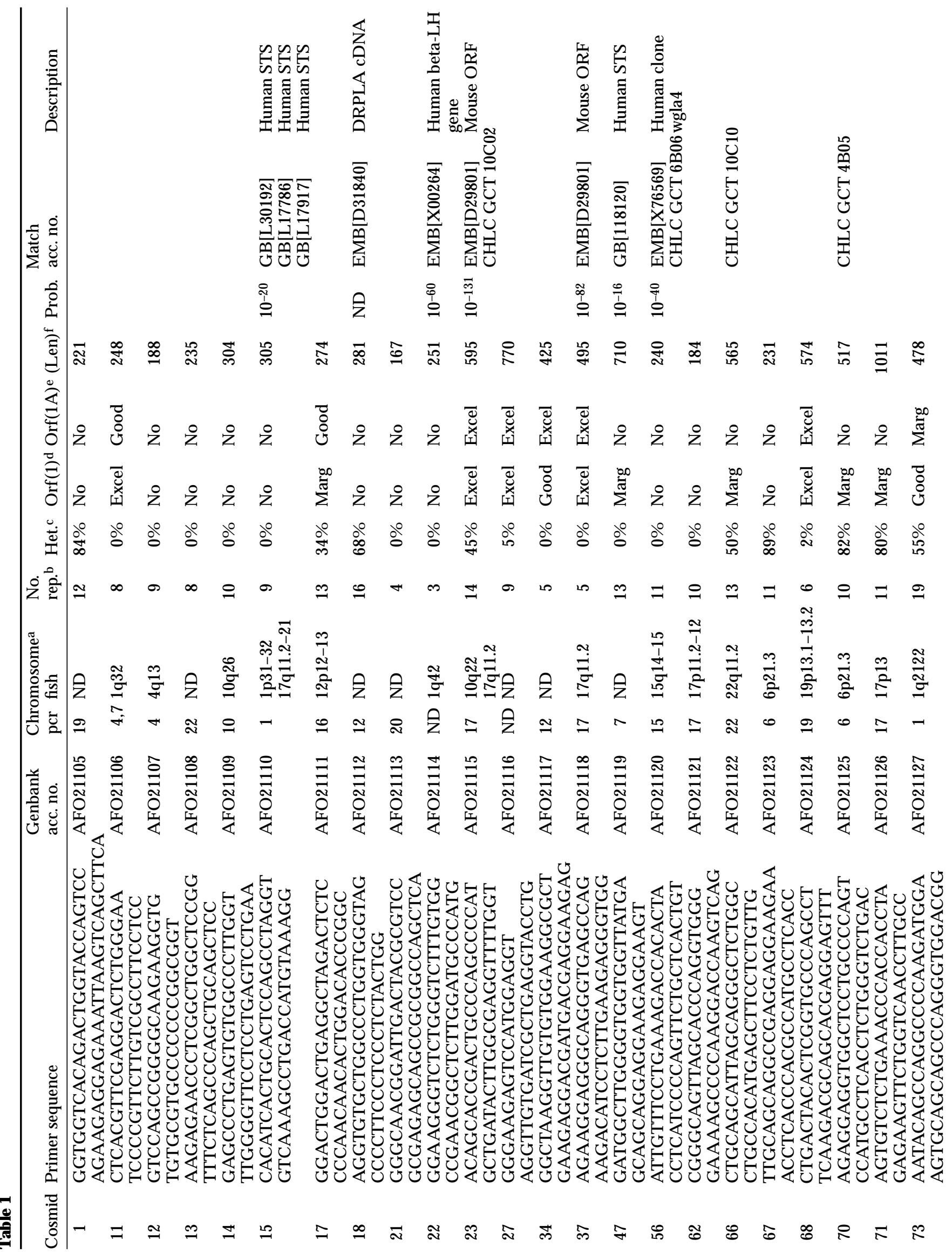




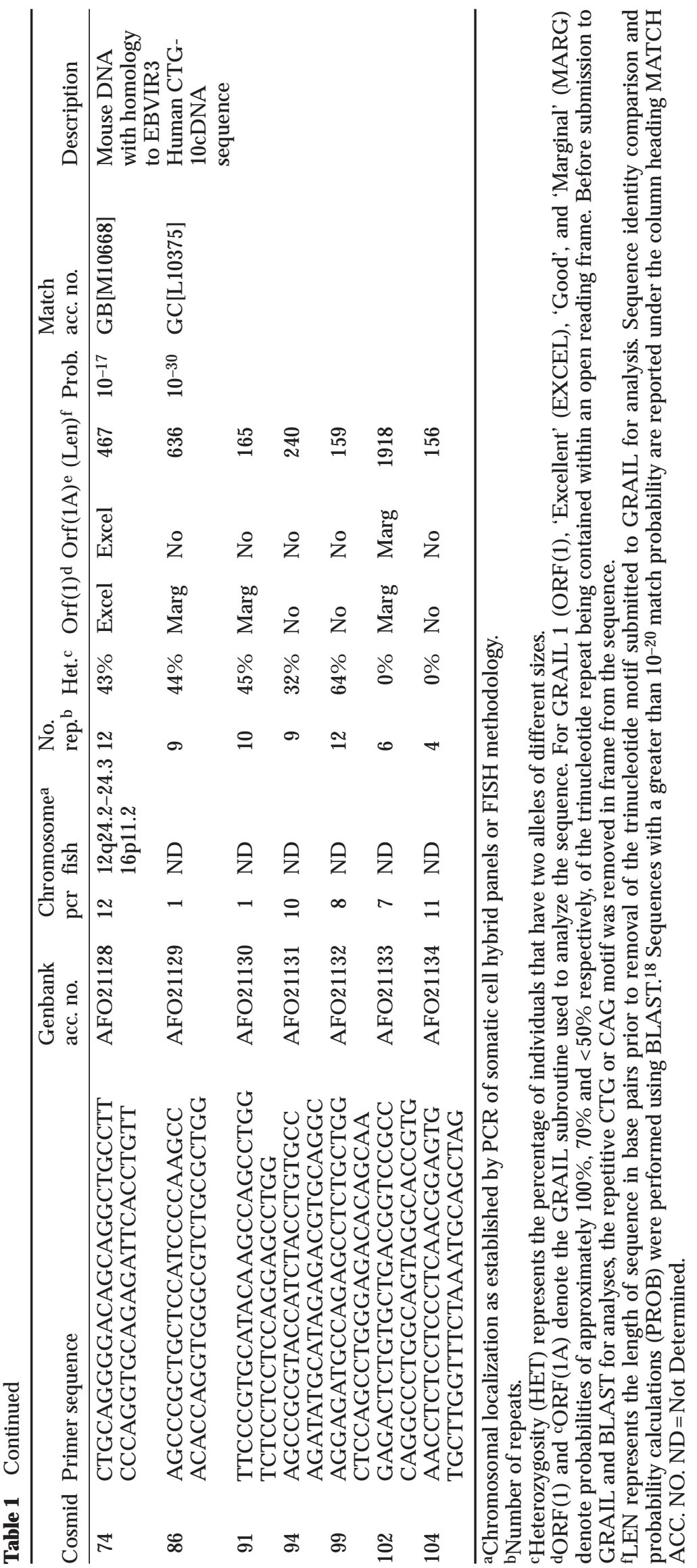


units, some have additional short repeats adjacent to the CTG repeats. For example, CTG-1 and CTG-15, have large CA A or GA A repeats adjacent to the CTG repeat. The probability of each trinucleotide repeat being located within an exon was determined by the Gene Recognition and A nalysis Interlink (GRAIL) Program ${ }^{16}$ (Table 1). In order to avoid difficulties inherent in the analysis of repetitive DNA regions, the trinucleotide repeat was deleted before the GRAIL analyses. Despite the short length of many of the sequences submitted for GRAIL analysis, approximately one third of the sequences had a good or excellent probability of occurring in exons.

These trinucleotide-depleted sequences were also submitted using the B asic L ocal A lignment Search Tool $(B L A S T)^{15}$ for comparison to G enbank and Swiss Prot data banks. DNA in nine clones showed at least a mild degree $\left(p<10^{-15}\right)$ of sequence homology to database entries. R egions of cosmids CT G - 37 and CT G -23 show almost complete sequence identity to a mouse open reading frame $(O R F)$ encoding a central nervous system protein, while CTG-22 shows strong sequence identity with a region of beta-luteinizing hormone. Cosmid CT - 56 shows considerable sequence identity with wg1A (EMB(X76569)), a previously isolated trinucleotide repeat. ${ }^{24}$ Cosmid CTG-18 contains the genomic clone of the D R PLA CDNA clone. ${ }^{5} \mathrm{CTG}-86$ is similar to CTG-B 10, a trinucleotide-containing clone previously isolated from a human brain CD NA library. ${ }^{9}$ For the other 21 CTG repeat-containing clones, including five with a good or excellent probability of occurring in exons, no sequence homology to database entries was identified.

\section{Discussion}

$\mathrm{O}$ ur findings suggest that the direct sequencing of genomic trinucleotide repeat-containing clones is useful for studying the involvement of these repetitive regions in human disease. With a few exceptions, ${ }^{24-27}$ previous attempts to characterize large CTG repeats have utilized CDNA libraries, ${ }^{8,9}$ resulting in a bias toward over-represented, more clonable, and/or more abundant transcripts. This makes the isolation of the interesting, rare or less stable cD NA s difficult, and is in contrast to procedures using genomic libraries which tend to have a less biased representation of the total candidate gene pool.

The direct sequencing of cosmid clones ${ }^{13}$ has several advantages. First, the large trinucleotide repeats which tend to be eliminated using smaller plasmids are more stable in cosmids. Second, analysis of the genomic D NA sequence surrounding the repeat allows us to determine whether the repeat could be located within an exon. Third, the additional sequence available in a cosmid can be used to generate FISH probes, allowing for subchromosomal location of clone. The isolation of genomic trinucleotide repeats by subcloning filter hybridization enriched, PCR amplified, M bo-I digested genomic fragments can be an alternative to generation of a primary library, ${ }^{24}$ but these repetitive regions are often difficult to amplify, ${ }^{28}$ resulting in the isolation of smaller, less GC-rich repeats that provide much less sequence information.

Using an approach in which the repetitive CTG sequence is removed, G R A IL analyses indicated that at least one third of these sequences has good or excellent probability of being found in a coding exon. This may underestimate the frequency of O R F s since at least one sequence, CTG-18, which stands for part of the DRPLA locus, was not detected by this GRAIL analysis. This omission may have occurred because G R A IL sometimes fails to recognize coding exons less than 100 bp in length. In an analysis of genomic CTG repeat sequences obtained from GE NBA NK ${ }^{29}$ Stallings concluded that one third of CTG repeats and almost all CA G repeats were located in exons. 0 ur results are in good agreement with these previous findings.

Comparison of the repeat sequences in our study with those in GENBANK demonstrates that several have significant sequence identity with previously described DNA sequences. The finding that CTG -18 is a partial genomic clone for the DRPLA CDNA illustrates the usefulness of this approach to search for trinucleotide repeats that may be involved in human disease. B oth CT G-23 and CTG-37 have considerable sequence identity with different parts of murine ORF (D 29801). Interestingly, GR A IL predicts that, like the CAG repeats from the mouse ORF (D 29801), the repeats from CTG-23 and CTG-37 are exonic in humans. However, the murine repeats are much smaller, being only 2 or 3 CA G units in length. This suggests that the trinucleotide repeats on chromosome 17 represented by CT G -23 and CT G -37 expanded after the divergence of human and mouse genomes.

With two exceptions, CTG-11 and CT G-17, the FISH data confirm the somatic cell PCR localization results. Two of the repeat-containing cosmids, CTG-74 and CTG-15 map by FISH to two distinct loci. This observation may result from the presence of multiple 
copies of these trinucleotide repeats or suggest the presence of a gene family of related sequences. This is not surprising since at least one repeat, CTG -47 gives four allele fragments on PCR amplification of human genomic D NA . H owever, unlike CT G-74 and CT G-15, chromosome localization performed using somatic cell hybrids suggests that all the loci encoding CTG-47 repeat sequence are on chromosome 7 .

In summary, we demonstrate that direct sequencing of cosmid clones from a genomic library is a useful approach to isolating and characterizing DNA sequences containing trinucleotide repeats that could be involved in human disease. The chromosomal and sub-chromosomal localization data presented here provide sequences that may help to identify candidate genes for diseases mapping nearby or in yet to be localized syndromes.

\section{Acknowledgements}

We would like to thank M sK ay K uhns and M s Liz A Izona for manuscript preparation. RA P was in part supported by the Pharmacology R esearch Training Program, NIG MS.

\section{References}

1 Warren ST, Nelson D L : A dvances in molecular analysis of fragile X syndrome. JAMA 1994; 271: 536-542.

2 The $\mathrm{H}$ untington's D isease Collaborative R esearch $\mathrm{G}$ roup: A novel gene containing a trinucleotide repeat that is expanded and unstable on Huntington's disease chromosomes. Cell 1993; 72: 971-983.

3 Koshy BT, Zoghbi HY: The CAG/polyglutamine tract diseases: gene products and molecular pathogenesis. B rain Pathol 1997; 7: 927-942.

$4 \mathrm{~L}$ aSpada A R et al: A ndrogen receptor gene mutation in linked spinal and bulbar muscular atrophy. $\mathrm{N}$ ature 1992; 352: 77-79.

5 Koide $R$ et al: Unstable expansion of CAG repeat in hereditary dentatorubral-pallidoluysian atrophy (D R PL A ). Nature G enet 1994; 6: 14-18.

$6 \mathrm{H}$ arley $\mathrm{HG}$ et al: Expansion of an unstable DNA region and phenotypic variation in myotonic dystrophy. Nature 1992; 355: 545-546.

7 Buxton J et al: D etection of an unstable fragment of D NA specific to individuals with myotonic dystrophy. Nature 1992; 355: 547-548.

8 Riggins $\mathrm{G}$ J et al: Human genes containing polymorphic trinucleotide repeats. N ature G enet 1992; 2: 186-191.

$9 \mathrm{Li} \mathrm{S-H}$ et al: Novel triplet repeat containing genes in human brain: cloning, expression and length polymorphisms. G enomics 1993; 16: 572-579.

10 Neri $C$ et al: Survey of CAG/CTG repeats in human CD NA s representing new genes: candidates for inherited neurological disorders. Hum Mol Genet 1996; 5(7): 1001-1009.
11 Jiang JX, Deprez RH, Zwarthoff EC, R iegman PH: Characterization of four novel CA G repeat-containing CD NA s. G enomics 1995; 30(1): 91-93.

$12 \mathrm{~K}$ immel A R : Selection of clones from libraries: overview. In: Berger S, K immel A R (eds). M ethods in E nzymology. A cademic Press: N ew Y ork, 1987, vol 152, pp 393-398.

13 Philibert RA et al: Direct sequencing of trinucleotide repeats from cosmid genomic DNA templates. A nal Biochem 1995; 225: 372-374.

14 Wallace RB, Miyada CG: Guide to molecular cloning techniques. In B erger SL, K immel A R (eds). M ethods in E nzymology. A cademic Press, N ew Y ork, 1987, vol 152, pp 432-442.

$15 \mathrm{~A}$ Itschul SF et al: B asic local alignment search tool. J M ol Biol 1990; 215: 403-410.

$16 \mathrm{U}$ berbacher $\mathrm{EC}, \mathrm{Mural} \mathrm{RJ}$ : Locating protein-coding regions in human DNA sequences by a multiple sensorneural network approach. Proc Nat A cad Sci USA 1991; 88: 11261-11265.

17 Shah M B et al: U ser's guide to GR A IL and GENQUEST (Sequence analysis, gene assembly and sequence comparison systems) $\mathrm{E}$-mail servers and XGRAIL (version 1.2) and XGENQUEST (version 1.1) client-server systems. A vailable by anonymous ftp to arthur.epm.orn1.gov (128.219.9.76) from directory pub/xgrail or pub/xgenquest as file manual.grail-genquest. 1994.

18 L emieux N, D utrillaux B, V iegas-Pequignot E: A simple method for simultaneous R - or G -banding and fluorescence in situhybridization of small single copy genes. Cytogenetics Cell Genet 1992; 59: 311-312.

19 Tenhunen $\mathrm{K}$ et al: Molecular cloning, chromosomal assignment, and expression of the mouse aspartylglucosaminidase gene. G enomics 1995; 30: 244-250.

20 Lichter $P$ et al: $R$ apid detection of human chromosome 21 aberrations by in situ hybridization. Proc Natl Acad Sci USA 1988; 85: 9664-9668.

21 Pinkel $D$ et al: Fluorescence in situ hybridization with human chromosome-specific libraries: detection of trisomy 21 and translocations of chromosome 4. . Proc Natl A cad Sci USA 1988; 85: 9138-9142.

22 Rytkonen EM et al: The human gene for xanthine dehydrogenase (XDH) is localized on chromosome band 2q22. Cell G enet 1995; 68: 61-63.

23 Heiskanen $M$ et al: Visual mapping by fiber-FISH. G enomics 1995; 30: 31-36.

24 A rmour JAL, Neumann R, Gobert S, Jeffreys AJ: I solation of human simple repeat loci by hybridization selection. $\mathrm{H}$ um M ol G enet 1994; 3: 599-605.

25 Gastier J M et al: Survey of trinucleotide repeats in the human genome: assessment of their utility as genetic markers. H um M ol G enet 1995; 4: 1829-1836.

$26 \mathrm{G}$ astier J M et al: D evelopment of a screening set for new (CA G/CTG) $n$ dynamic mutations. Genomics 1996; 32 75-85.

27 Sunden SLF et al: Chromosomal assignment of 2900 triand tetranucleotide repeat markers using NIG M S somatic cell hybrid panel 2. G enomics 1996; 32: 15-20.

28 Reiss $A$ J et al: Frequency and stability of the fragile $X$ mutation. H um M ol G enet 1994; 3: 393-398.

29 Stallings RL: Distribution of trinucleotide microsatellites in different categories of mammalian genomic sequence: implication for human genetic diseases. G enomics 1994; 21: 116-121. 